This is a post-print version of the following article:

Galán-Mañas, Anabel (2016). Learning portfolio in translator training: the tool of choice for competence development and assessment. The Interpreter and Translator Trainer, 10(2): 161182. DOI: $10.1080 / 1750399 \times .2015 .1103108$

http://dx.doi.org/10.1080/1750399X.2015.1103108

\title{
Learning portfolio in translator training: the tool of choice for competence development and assessment
}

\begin{abstract}
This article presents a practical example of the implementation of learning portfolios as a means to assessing competence in translator training. Details are given of how a portfolio may be used for both formative and summative assessment; the stages of competence development at which assessment should take place; and the criteria used for assessing the outcome of activities designed to develop translation competence. The results obtained are presented and discussed. The example presented shows that learning portfolios are the instruments of choice for assessing the progressive development of competence in trainee translators. They encourage learner autonomy, reflective and critical thinking and selfassessment, and the tasks set mobilise all the competences required to successfully develop translation competence. The use of learning portfolios, however, requires close collaboration between trainers and trainees, and a sustained effort to establish, and apply, effective competence assessment criteria.
\end{abstract}

\section{Introduction}

Current European Higher Education Area (EHEA) demands for university degree programmes to focus attention on competence development have brought about the need for effective competence assessment tools. A learning portfolio is one of a number of tools that may be used to assess competence development in any given subject. The notion of competence is reflected in an individual's ability to mobilise resources (Scallon 2004, 107); that is, students must face a challenge or solve a problem by applying knowledge that has been acquired, and integrated into a pre-existing knowledge structure, to the new situation.

In competence-based learning, therefore, assessment should reflect as many authentic situations as possible in which students are required to mobilise their acquired knowledge, thus demonstrating their competence in carrying out different tasks. Learning portfolios present a range of problem situations for which solutions must be found, thereby reflecting the level of students' competence development. They also require students to reflect upon the degree to which they have developed their competences, thus providing them with the means for monitoring and assessing their own learning.

Learning portfolios have evolved from the professional portfolios used by artists and architects to showcase examples of their work. Within academic institutions, not only do they showcase students' work, they also serve to develop reflective and critical thinking skills, and to assess performance.

Knapp (1975) provided one of the first definitions of a learning portfolio. He described it as a collection of a student's accomplishments which may be used as an instrument to select and organise his/her experiences for the purposes of assessment, or to document a student's learning process that reflects the objectives attained and assessed for the purposes of accreditation or academic recognition. 
According to Paulson, Paulson, and Meyer (1991), Davies and Lemathieu (2003) and Driessen et al. (2005), a learning portfolio not only provides evidence of a student's performance, but it also, by way of critical analysis of its contents, reflects a student's personal and professional development. Other authors (Colén, Giné, Imbernón 2006, 50; Prendes and Mar 2010; David et al. 2001) claim that a learning portfolio is not just a tool for assessment, but a means of monitoring and self-regulating the learning process, evidencing the acquisition of competences and testifying to the fact that course content has been understood and assimilated.

Within an academic context, therefore, learning portfolios serve both as a tool for summative assessment, since students collect evidence of their accomplishments, and formative assessment as students critically reflect on their learning process and competence development.

In the field of translation studies few tools have been developed specifically for the assessment of competence in trainee translators. Most have been designed to assess the translation product (Palazuelos, Hörmann, and Garbarini 1992; Kupsch-Losereit 1985; Kussmaul 1995; Hurtado 1996) or for more holistic assessment (Waddington 2000; Mahn 1989; Lowe 1987; Stansfield, Scott, and Kenyon 1992). The studies conducted by Townsend, Fu, and Lamme (1997) show that when assessing trainee translators' performance most translator trainers tend to focus their attention on the quality of the final product, the translated text. This finding flags up the need to redefine the aim of assessment in translator training so that greater importance is given to assessment as a means of enhancing learning. Learning portfolios, in this case, are the formative tools of choice.

The use of learning portfolios in translator training has not been widely commented on in the literature. For Johnson (2003), portfolios are intended primarily for use as summative assessment tools. She proposes guidelines and comments that underscore their links to professional portfolios. Colina (2003) defines portfolios as a set of translation assignments designed to introduce students to a variety of tasks and texts that professional translators engage in. Rojas (2004) sees portfolios as a complementary activity to formal training. Kelly (2005) proposes their use as an alternative method of assessment in translation pedagogy. Haiyan (2006) suggests several ways in which portfolio assessment may be applied to translation teaching. Rotheneder (2007) believes that creating and using a portfolio combines all the elements conducive to employability and provides a series of case studies. Hurtado $(2007,2008)$ focuses on task related assessment of specific competences and proposes the use of learning portfolios for assessment purposes. Galán-Mañas (2009) supports the use of learning portfolios in competence-based learning curricula and suggests the possible content of a portfolio. Rico (2010) and Fernández Polo and Cal (2011) present a case-study of assessment using learning portfolios in translation teaching. Finally, Fadeeva (2011) supports portfolios as an alternative form of assessment that contributes towards a student's lifelong learning.

This article presents a practical example of how translator trainees may be assessed using a learning portfolio. Details are given of how the portfolio has been used to assess the development of translation competence in first-year English to Spanish translator trainees in the Faculty of Translation and Interpreting of the Universitat Autònoma de Barcelona.

\section{Using learning portfolios for competence assessment of first-year translator trainees}

Designed to assess students' ability to apply acquired knowledge of different aspects of translation practice at different stages of their learning process, the learning portfolio presented served both as a tool for formative assessment and as a means to providing summative assessment. Summative assessment is necessary to satisfy institutional demands for marks at the end of students' competence-based learning process in the subject 
'Introduction to Translation' programmed in the second semester of the first year of their degree course in Translation and Interpreting in the Universitat Autònoma de Barcelona.

\section{1. 'Introduction to translation'}

The subject 'Introduction to Translation' accounts for 6 credits in the European Credit Transfer System - equivalent to a student workload of 150 hours. It lasts one semester. The number of students enrolled in the subject for each year surveyed varies from 31 to 59, as shown in Table 1.

Table 1. Number of students enrolled

\begin{tabular}{l|l}
\hline Academic year & No. of students \\
\hline $2009-10$ & 31 \\
\hline $2010-11$ & 33 \\
\hline $2011-12$ & 59 \\
\hline $2012-13$ & 42 \\
\hline
\end{tabular}

The aim of this subject is to introduce students to the basic principles of professional translation practice and to make them aware of contrastive aspects of the English-Spanish language pair.

According to the guidelines issued by the Faculty's Academic Committee, the subjectspecific competences to be developed during the semester include the ability to:

(1) produce texts in the A language1 (Spanish) for the purposes of translation; solving interferences between English and Spanish; identifying basic translation problems in a non-specialist text written in standard language; and recognising the textual, dynamic nature of translation equivalence;

(2) understand texts written in a foreign language (English) for the purposes of translation;

(3) use technologies for the purposes of translation;

(4) use documentary resources for the purposes of translation;

(5) document professional aspects of translation (employability, rights and obligations of the translator).

The cross-curricular competence to be assessed was the ability to:

(6) undertake lifelong, strategic, autonomous learning by drawing a plan of action to continue learning.

\subsection{Contents of the students' learning portfolios}

The contents of the students' learning portfolios focused exclusively on the subject of translation, although, given the multidisciplinary nature of translator training, they also touched on topics such as documentation, information technology, and Spanish and English.

The structure of the portfolio was determined by the teacher. However, students had the opportunity to submit samples of their learning outcomes which they themselves had selected, based on self-assessment, and which they deemed best reflected their accomplishments. To ensure that all tasks submitted satisfied assessment requirements, students were provided with a rubric describing assessment criteria (Appendix 1).

The contents of the portfolio were structured as follows:

(1) Diagnostic assessment (questionnaire, translation)

(2) Self-assessment (diagnostic questionnaire report, self-assessment reports)

(3) Usefulness of (electronic) resources for translation purposes (templates)

(4) Translations and reports on translations 
(5) Revised versions of translations

(6) Report on a forum

(7) Summaries of two public lectures

(8) Contrastive aspects of language.

The learning portfolio thus devised provided information on both the outcome of learning (translation performance as reflected in the target texts produced) and on the learning process itself (as reflected in the students' self-assessment reports). More detailed information on the contents of the portfolio now follows.

\subsubsection{Diagnostic assessment}

Diagnostic assessment was performed before initiating the learning process. Aimed at determining the knowledge of translation that students possessed prior to beginning their course, and based on the questionnaire produced by Orozco and Hurtado (2002), students were required to translate a text, respond to questions about the text, about the process followed during the translation of the text, the tools they used, the problems encountered and the way in which they were resolved.

\subsubsection{Self-assessment}

Students' self-assessment of their abilities and knowledge was developed and evidenced through the use of self-assessment questionnaires and written reports. This helped students appraise their own learning process.

Reports were provided at regular intervals throughout the semester on:

- students' concept of translation and their expectations regarding the translating profession before beginning their studies;

- students' expectations regarding the subject and its usefulness for their future career as a translator; its relationship with other subjects in the degree course etc.;

- what students had learnt during the semester, including descriptions of classroom activities that had evidenced the progress they had made;

- work that students had done during the semester; what had not been clearly understood; what had to be improved, etc. (claims in this respect had to be justified);

- goals set by students based on their self-assessment.

At the end of the semester, the diagnostic questionnaire was again administered to the students. The comparison of their answers to both questionnaires (at the beginning and at the end of the semester) served to demonstrate the extent to which their concept of translation had evolved over time.

Assessment took into account the depth of students' reflective analysis of their learning process and how realistic the goals were that they had set themselves for new learning in the short, medium and long term, according to competence 6.

\subsubsection{Usefulness of (electronic) resources for translation purposes}

Students were required to analyse the usefulness of three different types of electronic resources for translation purposes from each of the following categories: monolingual dictionaries in English and Spanish, Spanish-English bilingual dictionaries, distribution lists and forums of possible use to translators, machine translation software pertaining to the language pair under study, style books, and usage guides in Spanish. Instructions were given as to how to proceed and what information was to be given.

Assessment of competence 4 took into account the accuracy of the description of each of the resources selected and the degree of critical analysis of each of the data required. 


\subsubsection{Translations and reports on translations}

Students were required to include 5 non-specialised translations (250-300 words approx.), in their own time and within a period of several days. The translations were submitted together with a report which described two to four translation problems found during the translation process. Information had to be given as to whether or not the problems had been solved, the process used to solve the problems, and the resources used.

The fact that students had to submit several translations required the application of different skills and strategies for each new brief. The competences assessed were 1, 2, 3, 4 and 6.

\subsubsection{Revised versions of translations}

Once the teacher had returned the students' translations, in which the types of translation problems that had not been successfully resolved had been indicated, students were required to rework three of their translations.

Competences 1, 2, 3, 4 and 6 were assessed taking into account the translation problems which the students had not detected in the first version of their translations but which had been resolved in the revised version. Since the teacher had already drawn attention to the type of translation problem involved, it was the students' responsibility to apply the appropriate strategy to solve it.

\subsubsection{Report on a forum}

One of the ongoing activities throughout the semester was students' participation in a forum on the university's digital platform on the subject of the translation market. Before taking part in the forum, students were advised to first read supplementary material. Participants in the forum were encouraged to discuss job opportunities for graduates in translation and interpreting; general and specialised English-Spanish translations or related tasks that might be required of translators; companies and agencies that might need the services of translators, perhaps linking the type of company with the type of translation service provision task; and the rights and duties of translators.

Competence 5 was assessed taking into account which of the main translation associations and portals of the translation market each student named; whether or not the services they provided were available only to members or were available to all-comers; what the main openings were for professional translators; what tasks might be required of professional translators; and what the rights and duties of a professional translator were.

\subsubsection{Summary of two public lectures}

During the semester, students were required to attend two public lectures of interest to them either on the subject of translation or any other specialist field of interest to the translation market (law, medicine, etc.). A summary of a least one page in length had to be submitted for each lecture in order to assess competence 6 .

\subsubsection{Contrastive aspects of language}

Work on contrastive aspects of the English-Spanish language pair focused on interference of the source text language in the Spanish target text. Students were required to analyse a translated text in Spanish which presented examples of interference from the English language source text and classify the examples of interference (e.g. as morphosyntactic, lexical, punctuation, etc.), and to suggest how and why this interference had occurred and how it could be avoided in future. Competence 1 was assessed.

\section{Contents assessment}


Learning portfolios are not only tools for formative assessment; they are also tools for summative assessment. This is important, since several studies have shown that activities which are assessed have a greater effect on learning (Harris, Dolan, and Fairbairn 2001; Corcoran and Nicholson 2004; Dolan, Fairbairn, and Harris 2004) because students make a greater effort.

The marks given to students' portfolios may represent the overall mark for a subject, although the portfolio may be given a smaller percentage of the overall mark, and the portfolio mark may then be averaged into the marks given on other learning activities. If the mark given to a portfolio represents the overall mark given for a subject, a percentage of that mark may be apportioned to each of the different tasks included in the portfolio.

This was the case in the practical example of the use of portfolios described in this article. Table 2 shows the percentage of the total mark given to each task assessed and included in the portfolio:

Table 2. Summative assessment of learning portfolio contents.

\begin{tabular}{|l|l|}
\hline CONTENT Percentage of the total mark \\
\hline $\begin{array}{l}\text { 1. Diagnostic assessment } \\
\text { Initial questionnaire }\end{array}$ & $0 \%$ \\
\hline $\begin{array}{l}\text { 2. Self-assessment } \\
\text { diagnostic questionnaire }\end{array} \quad$ and progress report on the & \\
\hline$\quad \quad$ Translations ${ }^{1}$ & $9 \%$ \\
\hline 3. Usefulness of (electronic) resources for the purposes of translation & $10 \%$ \\
\hline 4. Five translations & $47 \%$ \\
\hline 5. Revised versions of translations ${ }^{3}$ & $3 \%$ \\
\hline 6. Report on a forum & $6 \%$ \\
\hline 7. Summary of two public lectures ${ }^{4}$ & $2 \%$ \\
\hline 8. Contrastive aspects of language & $3 \%$ \\
\hline
\end{tabular}

\subsection{When to assess}

Assessment on completion of a teaching unit helps retain acquired knowledge (Morales 1995, 19). Thus, in order to consolidate learning, we believe that the contents of a portfolio should not be submitted all together at the end of a course, but rather that they should be submitted at regular intervals throughout the course. Morales $(1995,20-24)$ and Van Lier $(2000,252)$ also link the frequency of assessment activities with improved performance because students become familiar with the criteria their teacher uses; they consolidate what they have learnt; they focus their attention on more important aspects of competence development; and, at the same time as they are able to repeatedly practise what they have learnt, they become increasingly aware of what they have yet to learn.

The different tasks included in the portfolio content described were submitted at regular intervals during the course so that students could monitor and self-regulate their learning process. This gave students who had not yet acquired the necessary competences time to improve their performance as well as provide them with further opportunities for competence development.

The schedule for portfolio submissions used is shown in Table 3.

Table 3. Schedule for portfolio submissions.

\footnotetext{
${ }^{1}$ Percentage given to each translation: $4 \%+4 \%+10 \%+12 \%+17 \%$

${ }^{2}$ Percentage given to each report: $0.5 \%+0.5 \%+0.5 \%+0.5+1 \%$

${ }^{3}$ Percentage given to each revised version: $0.5 \%+0.5 \%+1 \%+1 \%+3 \%$

${ }^{4}$ Percentage given to each summary: $1.5 \%+1.5 \%$
} 
1. Diagnostic assessment

2. Self-assessment

3. Usefulness of (electronic) resources for the purposes of translation

4. Five translations and reports on each

5. Revision of translations

6. Report on a forum

7. Summary of two public lectures

8. Contrastive aspects of language
Week 1

Week 15

Week 4

Weeks 6, 8, 10, 12, 14

Weeks 7, 9, 11, 13, 15

Week 10

Week 15

Week 5

\subsection{Assessment criteria}

A rubric (Appendix 1) similar to that proposed by Andrade (2005) and Mertler (2001) was used to assess students' learning portfolios.

The aim of a rubric is to clarify what is expected of students' work and how their work will be assessed. The description of the outcome of a product or task in terms of various levels of achievement provides them with feedback, which, as suggested by Fernández March (2010, 24), encourages students' self-regulation of their learning process. Rubrics also enable teachers to assess students' efforts more objectively and consistently while reducing the time spent on evaluation.

For portfolio assessment purposes in the example presented in this article, a rubric was used for each of the activities included in the portfolio content. Four levels of achievement were described for each of the activities.

The assessment criteria proposed by Hurtado $(1999,120)$ were adapted and used for assessing students' translations. The aim of using these criteria was to make students aware of and able to categorise successful or unsuccessful solutions for translation problems.

\section{Findings}

\subsection{Grades}

To determine the usefulness of the learning portfolio as an effective tool for summative assessment, a comparison was made of the grades registered in the academic records of first-year students studying English-Spanish translation from 2007 to 2013.

The marks obtained by students enrolled in the subject 'Introduction to Translation' from 2009 to 2013, when learning portfolios were used for assessment purposes, were compared with those of students studying first-year English-Spanish translation in the years immediately preceding 2009, when learning portfolios were not used.

Table 4 shows the percentage of students enrolled in the first-year English-Spanish translation course who were not assessed; and the percentage of those who obtained grades such as Fail, Pass, Very Good and Excellent.

Table 4. Students enrolled

\begin{tabular}{|l|c|c|c|c|c|c|}
\hline & $2007-2008$ & $2008-2009$ & $2009-2010$ & $2010-2011$ & $2011-2012$ & $2012-2013$ \\
\hline Not Assessed & 2.86 & 2.56 & 12.90 & 9.09 & 15.22 & 14.29 \\
\hline Fail & 11.43 & 12.82 & 3.23 & 0.00 & 0.00 & 7.14 \\
\hline Pass & 28.57 & 28.21 & 22.58 & 42.42 & 28.82 & 26.19 \\
\hline Very Good & 37.14 & 35.90 & 58.06 & 39.39 & 47.50 & 45.24 \\
\hline Excellent & 20.00 & 20.51 & 3.23 & 9.09 & 8.46 & 7.14 \\
\hline
\end{tabular}

Given that the learning portfolio was first used as a tool for assessment in 2009 when the university introduced the new EHEA-compatible degree in translation and interpreting, marked differences may be observed in the grades registered after this date, which may, no doubt, be attributable to the introduction of the learning portfolio. 
Four factors help contextualise our findings. First, the number of students who did not present themselves for assessment increased after the introduction of the portfolio. Two circumstances may account for this. Whilst pre-2009 students had the possibility of sitting examinations at one of two calls, this possibility did not exist with the new EHEA-compatible degree. Thus, students who did not think they would pass the subject at their first attempt did not take the examination because, if they did not pass, they would have to enrol in the same subject the following year and at greater expense.Moreover, since assessment was ongoing throughout the semester, a more sustained effort was required of students. This meant that students who also had a job, or those who could not attend class regularly, found it difficult to keep up with the subject and so decided not to take the assessment.

Secondly, the percentage of students failing the subject dropped after the introduction of the portfolio, to the point where in 2010 and 2011 no students failed. This would indicate either that the possibility of obtaining a positive overall assessment is greater when tasks are submitted regularly for assessment throughout the semester, rather than at final examination or when a limited number of activities are assessed; or that students who decide to continue their studies are those who really work hard.

Thirdly, while the percentage of students with a Pass mark peaked in 2010, the percentage of students with this mark proved to be fairly stable from 2011 to 2013. The number of students with Very Good marks increased.

Finally, the number of students whose marks were classified as Excellent dropped drastically. This would appear to show that it is much more difficult to demonstrate excellence in performance in tasks undertaken regularly over a period of time than on one specific occasion, at final examination. It must therefore be presumed that overall achievement assessed as Excellent is indicative of the effective sustained development of the different competences required in translation practice (see 2.2).

\subsection{Assessment of overall achievement}

In 2009, coinciding with the introduction of the use of learning portfolios for assessment purposes, students were invited to give themselves the grade (1-5) they believed they deserved for the subject. The grade they gave was independent of that given by the teacher. The purpose of this self-assessment was to contrast their perception of their achievements with that of the teacher.

It was thought that if serious discrepancies existed between what the students thought they were capable of doing and the teacher's assessment of what they were really capable of doing, this would disprove the proposed usefulness of the learning portfolio in translation competence development.

The figures below show the grades given by four successive cohorts of students and the teacher, the $x$ axis representing the number of students and the $y$ axis, the grades. Figures 1-4 show that the grades the teacher gave to the students and those the students gave themselves largely coincided in the different cohorts. Only in 2010-2011 did the grade Very Good vary markedly (20\%) between the students' self-assessment and the grade given by the teacher. I believe this is an outlier, which has not occurred since. 


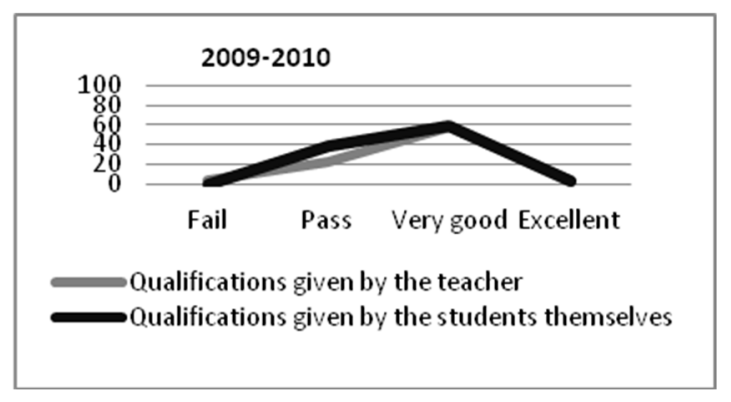

Fig. 1. Qualifications 2009-10.

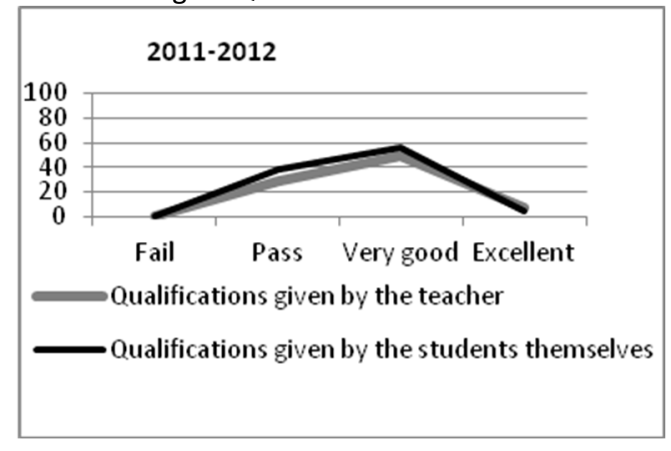

Fig. 3. Qualifications 2011-12.

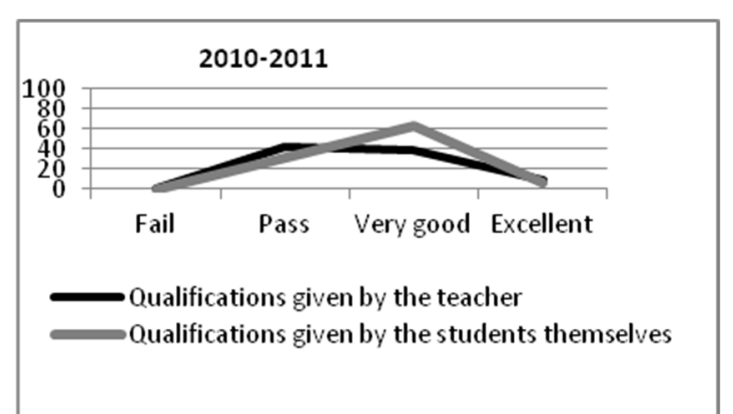

Fig. 2. Qualifications 2010-11.

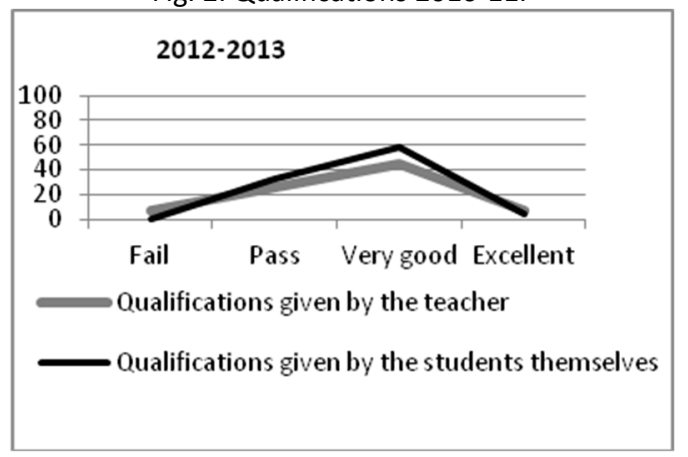

Fig. 4. Qualifications 2012-13.

\subsection{Evaluation of the learning portfolio as a tool for assessment}

At the end of the semester, students were given a questionnaire in which they were asked to give their opinion concerning the usefulness of the learning portfolio (Q1-Q5) and then to answer five other open questions (Q6-Q10).

A total of $81.35 \%$ of students answered the questionnaire in $2011-12$ and $45.23 \%$ in 2012-13. The results obtained from both cohorts are shown together below:

Q1. I found the learning portfolio useful as a means to reflecting on my learning process.

Q2. I found the learning portfolio useful for the teacher's assessment of my work.

Over $83 \%$ of students found the learning portfolio useful as a means to reflect on their learning process (see Figure 5) and 76\%believed it was useful for the teacher's assessment of their work (see Figure 6).

Q3. I found the learning portfolio useful for showcasing my achievements in the future because it has helped me reflect on what I need to include in my professional portfolio.

Q4. I find the learning portfolio useful for setting my learning goals for the future.

$70 \%$ of students agreed or totally agreed that the learning portfolio helped them to plan learning goals for the future (see Figure 8). Their opinion about the portfolio as a means to determining what they would include in their professional portfolio was, however, mixed ( $46 \%$ 'quite useful'; $24 \%$ 'very useful'; $26 \%$ 'fairly useful') (see Figure 7 ). 


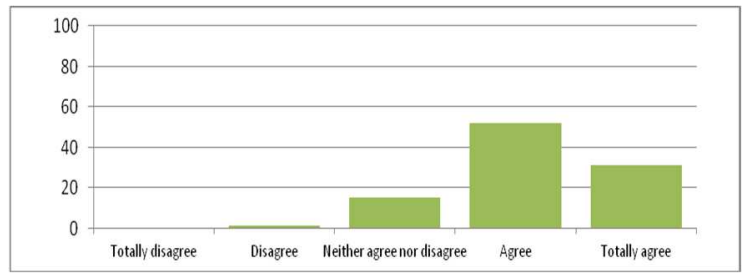

Fig. 5. The learning portfolio as a means to reflect on the learning process.

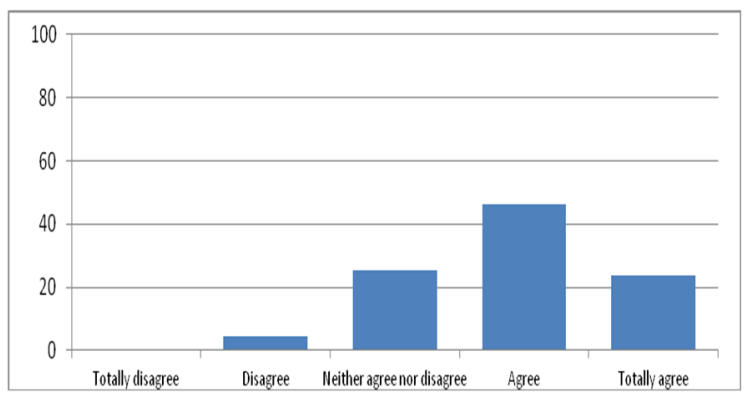

Fig. 7. Usefulness of the learning portfolio for showcasing the students' achievements in the future.

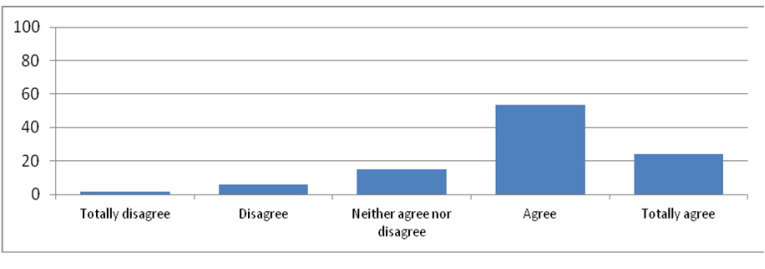

Fig. 6. Usefulness of the learning portfolio for the teacher's assessment.

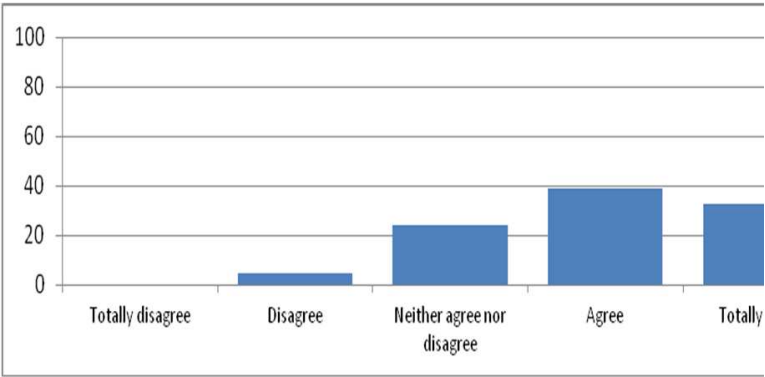

Fig. 8. Usefulness of the learning portfolio for setting one's learning goals.

Q5. I found the learning portfolio useful for revising the work we did throughout the semester.

Q6. The instructions I received as to how to compile the portfolio were clear.

Almost all students found that the learning portfolio was very useful for revising all the work done during the semester (see figure 9). They also rated highly the clarity of the instructions given for compiling the portfolio (see Figure 10).

\section{Q7. I have spent (. . . hours) compiling my portfolio.}

Students spent on average 11.75 hours in compiling their learning portfolio.

Q8. I consulted the rubric we were given before submitting each activity and the complete portfolio.

Before submitting their portfolio, $87 \%$ of students consulted the rubric describing assessment criteria, whilst $13 \%$ had not been aware that the rubric was available together with the instructions for compiling the portfolio (see figure 11 ).

\section{Q9. I found the following problems when compiling my portfolio.}

The most common problems that the students found were: it was the first time that they had had to reflect upon their learning process and they did not know how to express themselves; they found it difficult to summarise the contents of the self-assessment section; they found it difficult to organise the content of the portfolio; they found it difficult to revise the translations they had been given, despite the fact that the teacher had indicated the type of translation problem they had to solve (see 3.2. above); they found that the portfolio required a lot of effort and reflexion; they found it difficult to select examples of their learning outcomes; and they found it difficult to establish their learning goals for the future. 


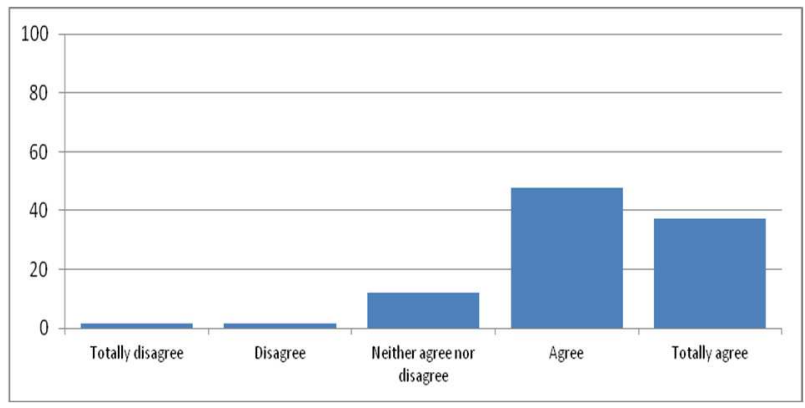

Fig. 9. Usefulness of the learning portfolio for revising the work.

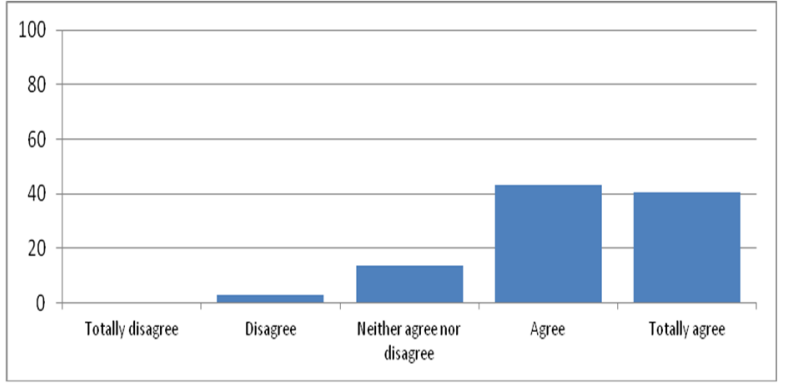

Fig.10. Clearness of the instructions received.

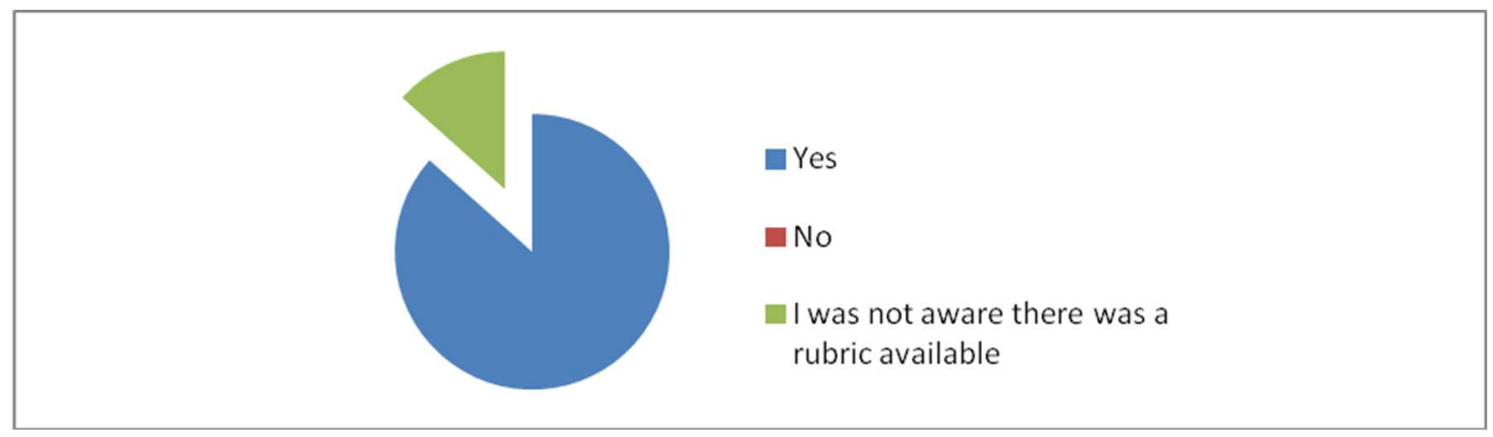

Figure 11. Consultation of the rubric.

Q10. I would include the following material in the learning portfolio.

Almost all students stated that they believed that the contents of the portfolio were very compehensive. A small minority stated that they would like to have included more translations with their respective revisions. Most students stated that nothing should be added as the portfolio was a 'compendium of everything that had been done in class'. Five students, however, felt that all the translations that had been done in class should have been included so that they could 'see their progress'. This shows that the purpose of the portfolio - that is, assessment as opposed to showcasing students' achievements - should have been explained.

\section{Q11. I would eliminate the following elements from the portfolio.}

Almost all students stated that they would not eliminate any element from the portfolio 'since each of the elements included complemented what had been learnt'. Only one student suggested eliminating the reflexion on the diagnostic assessment.

\section{Q12. Make any further observations you wish concerning the learning portfolio.}

Most students highlighted the usefulness of the learning portfolio, in particular because it developed their reflective thinking skills and because it had made them succintly summarise all the work they had done during the semester. They also pointed to the fact that they had learnt to recognise their shortcomings and to set themselves learning goals for the future. They said the portfolio had helped them to see what they had learnt and how much they had learnt in a very short time. They also referred to the fact that the rubric used for assessment was particularly useful. 
Students' negative comments about the use of the learning portfolio focused on the amount of work it involved.

Finally, one of the students stated what many had informally commented: 'At the beginning I didn't think the portfolio was going to be useful, but I now realise it is. Perhaps portfolios should be used in all subjects.'

\section{Conclusions}

The use of learning portfolios in competence-based translator training gives students the means to showcase their accomplishments and competences through different tasks. These tasks have an executive function, as students need to select and apply different strategies and tools in every task.

The use of learning portfolios has other advantages:

- students organise themselves better, since they are given a timetable for the submission of assignments;

- by viewing their portfolio as a whole and choosing examples of their work, they become aware of their learning process and can reflect on the progress they have made;

- the range of different tasks that are included in the portfolio encourages the mobilisation of all the competences included in the course;

- students are provided with rubrics with which to assess their activities and to obtain feedback. Rubrics provide them with the means to self-regulate their learning process;

- teachers must overhaul their teaching methodology, since the use of portfolios changes their role in the classroom. Active classroom and assessment methodologies are required.

Some drawbacks, however, have also been noted:

- first-year students find it difficult to self-reflect on their learning process;

- creating a portfolio initially disconcerts students because of the range of assignments to be submitted during the semester;

- using portfolios considerably increases teachers' and students' workload. As well as assessing contents, teachers must scaffold students' tasks, helping them with their self-reflection and critical thinking. A possible alternative in the case study described would have been to reduce the number of activities submitted for assessment and devise more detailed rubrics so that students could be better guided in their tasks and the teacher could assess more quickly.

Considering these advantages and disadvantages, we believe portfolio-based learning in translation training should be encouraged because it provides the basis for lifelong learning (David et al. 2001; Van der Vleuten and Schuwirth 2005).

However, if the use of learning portfolios increases students' workload, one way of increasing motivation would be to show them professional portfolios so that a link can be established between what is being done in the university and what is being done in the professional workplace. A link can in fact be established between learning portfolios, professional translators' portfolios and students' CVs. The use of learning portfolios could represent a first step towards familiarising students with this tool, which may later be used as a presentation portfolio when starting out as a professional translator.

This article gives details on how a learning portfolio has been operationalised within a competence-based context. However, further research is required into the use of portfolios in other educational contexts, such as in specialised translation and with other language pairs. Learning portfolios should be compared with other assessment instruments and 
methodologies, and possible connections should be established between learning portfolios and professional portfolios.

\section{References}

Andrade, H. G. 2005. "Teaching With Rubrics: The Good, the Bad, and the Ugly." College Teaching 53 (1): 27-31. doi: 10.3200/CTCH.53.1.27-31.

Colén, M. T., N. Giné, and F. Imbernon. 2006. La carpeta de aprendizaje del alumnado universitario: la autonomía del estudiante en el proceso de aprendizaje. Barcelona: Octaedro.

Colina, S. 2003. Translation Teaching: From Research to the Classroom. New York: McGraw Hill. Corcoran, J., and C. Nicholson. 2004. "Learning Portfolios - Evidence of Learning: An Examination of Students' Perspectives." Nursing in Critical Care 9 (5): 230-237. doi: 10.1111/ncr.2004.9.issue-5.

David, M., B. Friedman, M. H. Davis, R. M. Harden, P. W. Howie, J. Ker, and M. J. Pippard. 2001. "AMEE Medical Education Guide No. 24: Portfolios as a Method of Student Assessment." Medical Teacher 23 (6): 535-551. doi: 10.1080/01421590120090952.

Davies, A., and P. Lemathieu. 2003. "Assessment for Learning: Reconsidering Portfolios and Research Evidence." In Optimising New Modes of Assessment: In Search of Qualities and Standards, edited by M. Segers and F. Dochy, 141-169. The Netherlands: Kluwer Academic Publishers.

Dolan, G., G. Fairbairn, and S. Harris. 2004. "Is Our Student Portfolio Valued?" Nurse Education Today 24 (1): 4-13. doi:10.1016/j.nedt.2003.08.002.

Driessen, E., C. Van Der Vleuten, L. Schuwirth, J. Van Tartwijk, and J. Vermunt. 2005. "The Use of Qualitative Research Criteria for Portfolio Assessment as an Alternative to Reliability Evaluation: A Case Study." Medical Education 39: 214-220. doi:10.1111/med.2005.39.issue-2.

Fadeeva, N. 2011. "An Analysis of Interpreter and Translator Training and Assessments Abroad." Journal of Siberian Federal University. Humanities \& Social Sciences 3: 400-409.

Fernández March, A. 2010. "La evaluación orientada al aprendizaje en un modelo de formación por competencias en la educación universitaria." Revista de Docencia Universitaria 8 (1): 1123.

Fernández Polo, F., and M. Cal. 2011. "Learning Translation through the Use of Portfolios: Description of an Experience." @tic. Revista d'innovació educativa 7: 44-51.

Galán-Mañas, A. 2009. "La enseñanza de la traducción en la modalidad semipresencial." PhD diss., Universitat Autònoma de Barcelona.

Haiyan, L. 2006. Cultivating Translator Competence: Teaching \& Testing. Translation Journal 10 (3). http://accurapid.com/journal/37testing.htm

Harris, S., G. Dolan, and G. Fairbairn. 2001. "Reflecting on the Use of Student Portfolios." Nurse Education Today 21 (4): 278-286. doi:10.1054/nedt.2000.0545.

Hurtado, A. 1996. "La enseñanza de la traducción directa general. Objetivos de aprendizaje y metodología." In La enseñanza de la traducción, edited by A. Hurtado, 31-56. Castellón: Servei de Publicacions de la UJI.

Hurtado, A., dir. 1999. Enseñar a traducir. Metodología en la formación de traductores e intérpretes. Madrid: Edelsa.

Hurtado, A. 2007. "Competence-Based Curriculum Design for Training Translators." The Interpreter and Translator Trainer 1 (2): 163-195. doi:10.1080/1750399X.2007.10798757.

Hurtado, A. 2008. "Compétence En Traduction Et Formation Par Compétences." Ttr 21 (1): 1764. doi:10.7202/029686ar. 
Johnson, J. 2003. "Learning through Portfolios in the Translation Classroom." In Beyond the Ivory Tower: Rethinking Translation Pedagogy, edited by B. Baer and G. Koby, 97-116. Amsterdam: John Benjamins.

Kelly, D. 2005. A Handbook for Translator Trainers. Manchester: St.Jerome.

Knapp, J. 1975. A Guide to Assessing Prior Experiences through Portfolios. Princeton: Educational Testing Service.

Kupsch-Losereit, S. 1985. "The Problem of Translation Error Evaluation." In Translation in Foreign Language Teaching and Testing, edited by C. Titford, 169-179. Tübingen: Narr.

Kussmaul, P. 1995. Training the Translator. Amsterdam: John Benjamins.

Lowe, P. 1987. "Revising the ACTFL/ETS Scales for a New Purpose: Rating Skill in Translating." In Translation Excellence: Assessment, Achievement, Maintenance, edited by M. Rose, 53-61. New York: SUNY Binghamton Press.

Mahn, G. 1989. "Standards and Evaluation in Translator Training." In Translator and Interpreter Training and Foreign Language Pedagogy, edited by P. Krawutschke, 100-108. New York: SUNY Binghamton Press.

Mertler, C. 2001. "Designing Scoring Rubrics for Your Class-Room." Practical Assessment Research and Evaluation 7 (25). Available at: http://pareonline.net/getvn.asp?v=7\&amp;n=25.

Morales, P. 1995. La evaluación académica: conceptos y planteamientos básicos. Bilbao: Universidad de Deusto.

Orozco, M., and A. Hurtado. 2002. "Measuring Translation Competence Acquisition." Méta 47 (3): 375-402.

Palazuelos, J., P. Hörmann, and C. Garbarini. 1992. El error en traducción. Santiago: Universidad Católica de Chile.

Paulson, L., P. Paulson, and C. Meyer. 1991. "What Makes a Portfolio a Portfolio?” Educational Leadership 48: 60-63.

Prendes, P., and S. Mar. 2010. "El portafolio como herramienta de evaluación." In Técnicas de evaluación en el EEES, edited by M. Porto. Murcia: Edit.um.

Rico, C. 2010. "Translator Training in the European Higher Education Area: Curriculum Design for the Bologna Process." The Interpreter and Translator Trainer 4 (1): 89-114. doi:10.1080/ 1750399X.2010.10798798.

Rojas, O. 2004. "El portafolio y la evaluación del proceso de traducción." Letras 1 (36): 27-64.

Rotheneder, N. 2007. "e-Learning and Employability in Translator Training: Introducing ePortfolio and Personal Development Planning at the University of Vienna." Translating and the Computer 29: 1-20.

Scallon, G. 2004. L'évaluation des apprentissages dans une approche par compétences. Quebec: Éditions Renouveau Pédagogique.

Stansfield, C. W., M. L. Scott, and D. M. Kenyon. 1992. "The Measurement of Translation Ability." The Modern Language Journal 76 (4): 455-467. doi:10.1111/modl.1992.76.issue-4.

Townsend, J. S., D. Fu, and L. L. Lamme. 1997. "Writing Assessment: Multiple Perspectives, Multiple Purposes." Preventing School Failure: Alternative Education for Children and Youth 41 (2): 71-76. doi:10.1080/10459889709603271.

Van der Vleuten, C., and L. Schuwirth. 2005. "Assessing Professional Competence: From Methods to Programmes." Medical Education 39: 309-317. doi:10.1111/med.2005.39.issue-3.

Van Lier, L. 2000. "From Input to Affordance. Socio-Interactive Learning from an Ecological Perspective." In Sociocultural Theory and Second Language Learning, edited by J. Lantolf, 245260. Oxford: Oxford University Press. 
Waddington, C. 2000. Estudio comparativo de diferentes métodos de evaluación de traducción general. Madrid: Universidad Pontificia Comillas. 


\begin{tabular}{|c|c|c|c|c|}
\hline CONTENT & FAIL & PASS & VERY GOOD & EXCELLENT \\
\hline Self-assessment & $\begin{array}{l}\text { - You do not give details of what you } \\
\text { expected to learn about translation } \\
\text { at the beginning of your course and } \\
\text { at the end. You have not included a } \\
\text { report on the progress you have } \\
\text { made. } \\
\text { - You do not indicate the usefulness } \\
\text { this subject may have for your future } \\
\text { career. } \\
\text { - You give no details of what you now } \\
\text { know about translation that you did } \\
\text { not know beforehand. } \\
\text { - You have not specified your } \\
\text { strengths and weaknesses in the } \\
\text { competences under study. } \\
\text { - You do not mention the learning } \\
\text { strategies you have applied. } \\
\text { - You provide no plan for future } \\
\text { improvement. } \\
\text { - The mark you have given your } \\
\text { portfolio is not based on the } \\
\text { established assessment criteria. } \\
\text { - You have made a lot of mistakes in } \\
\text { grammar, spelling and punctuation } \\
\text { (more than 13) in your self- } \\
\text { assessment report. }\end{array}$ & $\begin{array}{l}\text { - You give a brief description of what } \\
\text { you expected to learn about } \\
\text { translation at the beginning of your } \\
\text { course, and of how your initial } \\
\text { concept of translation has evolved. } \\
\text { Your comparison of your translation } \\
\text { at the beginning and at the end of } \\
\text { the semester is superficial, so that } \\
\text { you have not been able to evaluate } \\
\text { the progress you have made in this } \\
\text { subject } \\
\text { - You do not justify your opinion } \\
\text { concerning the usefulness this } \\
\text { subject may have for your future } \\
\text { career. } \\
\text { - You describe what you now know } \\
\text { about translation that you did not } \\
\text { know before, but you do not give } \\
\text { examples. } \\
\text { - You identify your strengths and } \\
\text { weaknesses with regard to what has } \\
\text { been studied in class but you do not } \\
\text { justify your opinion. } \\
\text { - You do not give examples of the } \\
\text { learning strategies you have applied. } \\
\text { - Your plan for improvement is vague } \\
\text { and lacks short, medium and long } \\
\text { term objectives. } \\
\text { - You have given your portfolio a mark } \\
\text { using your established assessment } \\
\text { criteria but you do not justify your } \\
\text { mark. } \\
\text { - You have made many mistakes in } \\
\text { grammar, spelling and punctuation } \\
\text { (9-12) in your self-assessment } \\
\text { report. }\end{array}$ & $\begin{array}{l}\text { - You describe what you expected to } \\
\text { learn about translation at the } \\
\text { beginning of your course and you } \\
\text { describe how your initial perception } \\
\text { of translation has evolved. You have } \\
\text { satisfactorily analysed the quality of } \\
\text { the translation you did at the } \\
\text { beginning and at the end of the } \\
\text { semester and you have been able to } \\
\text { justify the progress made in learning. } \\
\text { However, you should have included } \\
\text { more examples. } \\
\text { - You give a brief description of the } \\
\text { usefulness this subject may have for } \\
\text { your future career and you justify } \\
\text { your opinion. } \\
\text { - You give details of what you now } \\
\text { know about translation that you did } \\
\text { not know before, but the examples } \\
\text { you give are not pertinent. } \\
\text { - You identify your strengths and } \\
\text { weaknesses with regard to what you } \\
\text { have studied in class but you do not } \\
\text { justify your opinion with examples. } \\
\text { - You give examples of the learning } \\
\text { strategies you have applied but the } \\
\text { examples you give are not pertinent. } \\
\text { - Your plan for improvement is vague } \\
\text { and lacks clear short, medium and } \\
\text { long term objectives. } \\
\text { - You have justified the mark you have } \\
\text { given your portfolio, which reflects } \\
\text { established assessment criteria. } \\
\text { - You have made some mistakes in } \\
\text { grammar, spelling and punctuation } \\
\text { (4-8) in your self-assessment report. }\end{array}$ & $\begin{array}{l}\text { - You describe what you expected to learn } \\
\text { about translation at the beginning of your } \\
\text { course and you describe how your initial } \\
\text { perception of translation has evolved. You } \\
\text { show how this subject has enabled you to } \\
\text { progress in your learning and give examples } \\
\text { that reflect this opinion. You analyse the } \\
\text { quality of the translation you did at the } \\
\text { beginning and at the end of the semester. } \\
\text { - You describe the usefulness this subject may } \\
\text { have for your future career and you fully } \\
\text { justify your opinion. } \\
\text { - You give details of what you now know about } \\
\text { translation that you did not know before, and } \\
\text { you give examples that reflect your progress. } \\
\text { - You identify your strengths and weaknesses } \\
\text { with regard to what has been studied in class } \\
\text { and you give pertinent examples. } \\
\text { - You give examples of the learning strategies } \\
\text { you have applied and you give examples of } \\
\text { each. } \\
\text { - You provide a clear plan for improvement with } \\
\text { short, medium and long term objectives. } \\
\text { - The mark you have given your portfolio fulfils } \\
\text { established assessment criteria. } \\
\text { - You have made none or few mistakes in } \\
\text { grammar, spelling and punctuation (0-3) in } \\
\text { your self-assessment report. }\end{array}$ \\
\hline & $0-2.25$ & $2.26-4.50$ & $4.51-6.75$ & $6.76-9$ \\
\hline
\end{tabular}




\begin{tabular}{|c|c|c|c|c|}
\hline \multirow[t]{2}{*}{$\begin{array}{l}\text { Collection } \\
\text { and analysis } \\
\text { of resources } \\
\text { (electronic) } \\
\text { for the } \\
\text { purposes of } \\
\text { translation }\end{array}$} & $\begin{array}{l}\text { - You have not identified resources } \\
\text { from each of the categories you } \\
\text { were given. } \\
\text { - You have identified resources from } \\
\text { each of the categories given but you } \\
\text { have not presented a critical analysis } \\
\text { of any. } \\
\text { - You have not completed the } \\
\text { template provided so that you have } \\
\text { not analysed the usefulness of the } \\
\text { resources as required. }\end{array}$ & $\begin{array}{l}\text { - You have identified resources from } \\
\text { some of the categories given (fewer } \\
\text { than three). } \\
\text { - You have identified resources from } \\
\text { each of the categories given but you } \\
\text { have presented a critical analysis of } \\
\text { fewer than three. } \\
\text { - You have not used the template } \\
\text { provided so that you have not } \\
\text { analysed all aspects of the } \\
\text { usefulness of the resources, as } \\
\text { required. }\end{array}$ & $\begin{array}{l}\text { - You have identified electronic } \\
\text { resources from some of the } \\
\text { categories given (three to five). } \\
\text { - You have identified resources from } \\
\text { each of the categories given but you } \\
\text { have presented a critical analysis of } \\
\text { three to five. } \\
\text { - Using the template provided you } \\
\text { have presented a critical analysis of } \\
\text { the usefulness of most of the } \\
\text { resources identified. }\end{array}$ & $\begin{array}{l}\text { - You have identified electronic resources from } \\
\text { the categories given (more than five) } \\
\text { - You have identified resources from each of the } \\
\text { categories given and you have presented a } \\
\text { critical analysis of more than five. } \\
\text { - Using the template provided you have } \\
\text { presented a critical analysis of the usefulness } \\
\text { of each of the resources identified. }\end{array}$ \\
\hline & $0-2.4$ & $2.4-4.9$ & $4.9-7.4$ & $7.5-10$ \\
\hline \multirow{6}{*}{$\begin{array}{l}\text { Obligatory } \\
\text { translations }\end{array}$} & See evaluation criteria for translations & See evaluationcriteria for translations & See evaluationcriteria for translations & See evaluationcriteria for translations \\
\hline & 1) $0-0.9$ & 1) $1-1.9$ & 1) $2-2.9$ & 1) $3-4$ \\
\hline & 2) $0-0.9$ & 2) $1-1.9$ & 2) $2-2.9$ & $2) 3-4$ \\
\hline & 3) $0-2.4$ & 3) $2,4-4.9$ & 3) $4.9-7.4$ & 3) $7.5-10$ \\
\hline & 4)0-2.9 & 4) $3-5.9$ & 4) $6-8.9$ & 4) $9-12$ \\
\hline & 5) $0-4.24$ & 5) $4.25-8.49$ & 5) $8.5-12.74$ & 5) $12.75-17$ \\
\hline \multirow{6}{*}{$\begin{array}{l}\text { Reports on } \\
\text { translations }\end{array}$} & $\begin{array}{l}\text { - You do not include a report on each } \\
\text { completed translation. }\end{array}$ & $\begin{array}{l}\text { - Your reports describe the translation } \\
\text { problems encountered in each } \\
\text { translation but not the process you } \\
\text { followed to solve them. }\end{array}$ & $\begin{array}{l}\text { - Your reports describe the translation } \\
\text { problems encountered in each } \\
\text { translation and in most cases the } \\
\text { process you followed to solve them. }\end{array}$ & $\begin{array}{l}\text { - Your reports describe the translation problems } \\
\text { encountered in each translation and the } \\
\text { process you followed to solve each one. }\end{array}$ \\
\hline & 1) $0-0.124$ & 1) $0.125-0.24$ & 1) $0.25-0.374$ & 1) $0.375-0.5$ \\
\hline & 2) $0-0.124$ & 2) $0.125-0.24$ & 2) $0.25-0.374$ & 2) $0.375-0.5$ \\
\hline & 3) $0-0.124$ & 3) $0.125-0.24$ & 3) $0.25-0.374$ & 3) $0.375-0.5$ \\
\hline & 4) $0-0.124$ & 4) $0.125-0.24$ & 4) $0.25-0.374$ & 4) $0.375-0.5$ \\
\hline & 5) $0-0.24$ & 5) $0.25-0.49$ & 5) $0.49-0.74$ & 5) $0.75-1$ \\
\hline \multirow{6}{*}{$\begin{array}{l}\text { Revised } \\
\text { versions of } \\
\text { the } \\
\text { obligatory } \\
\text { translations }\end{array}$} & $\begin{array}{l}\text { - You have not used the feedback } \\
\text { provided by your teacher to rework } \\
\text { your translations. }\end{array}$ & $\begin{array}{l}\text { - You have only corrected some of the } \\
\text { mistakes in your translations using } \\
\text { feedback from your teacher }\end{array}$ & $\begin{array}{l}\text { - Your translation has improved } \\
\text { considerably. You have corrected } \\
\text { many of the mistakes you made, } \\
\text { using feedback from your teacher }\end{array}$ & $\begin{array}{l}\text { - Your translation has improved considerably. } \\
\text { You have corrected all of the mistakes pointed } \\
\text { out by your teacher. }\end{array}$ \\
\hline & 1) $0-0.124$ & 1) $0.125-0.24$ & 1) $0.25-0.374$ & 1) $0.375-0,5$ \\
\hline & 2) $0-0.124$ & 2) $0.125-0.24$ & 2) $0.25-0.374$ & 2) $0.375-0,5$ \\
\hline & 3) $0-0.240$ & 3) $0.25-0.49$ & 3) $0.5-0.74$ & 3) $0.75-1$ \\
\hline & 4) 0-0.24 & 4) $0.25-0.49$ & 4) $0.5-0.74$ & 4) $0.75-1$ \\
\hline & 5) $0-0.75$ & 5) $0.74-1.5$ & 5) $1.51-2.25$ & 5) $2.25-3$ \\
\hline
\end{tabular}




\begin{tabular}{|c|c|c|c|c|}
\hline \multirow[t]{2}{*}{$\begin{array}{l}\text { Report on } \\
\text { the forum on } \\
\text { the } \\
\text { translation } \\
\text { market }\end{array}$} & $\begin{array}{l}\text { - Your summary does not reflect the } \\
\text { ideas expressed in the forum. } \\
\text { - The data you present show that you } \\
\text { are unaware of translation market } \\
\text { conditions or translators' rights and } \\
\text { obligations. }\end{array}$ & $\begin{array}{l}\text { - Your summary reflects only some of } \\
\text { the ideas expressed in the forum. } \\
\text { You have not expressed your opinion } \\
\text { of these ideas. } \\
\text { - The data you present show that you } \\
\text { are aware of only one aspect of the } \\
\text { translation market mentioned in the } \\
\text { debate: the areas in which } \\
\text { professional translators may be } \\
\text { employed or translators' rights and } \\
\text { obligations. }\end{array}$ & $\begin{array}{l}\text { - Your summary reflects the main } \\
\text { ideas expressed in the forum, but } \\
\text { you have not expressed your } \\
\text { opinion. } \\
\text { - The data you present show that you } \\
\text { are aware of the areas in which } \\
\text { professional translators may be } \\
\text { employed as well as their rights and } \\
\text { obligations. }\end{array}$ & $\begin{array}{l}\text { - Your summary reflects the main ideas } \\
\text { expressed in the forum, and you express your } \\
\text { own opinion. } \\
\text { - The data you present show that you are aware } \\
\text { of the areas in which professional translators } \\
\text { may be employed as well as their rights and } \\
\text { obligations. }\end{array}$ \\
\hline & $0-0.4$ & $0.5-0.9$ & $1-1.49$ & $1.5-2$ \\
\hline \multirow[t]{2}{*}{$\begin{array}{l}\text { Summary of } \\
\text { two public } \\
\text { lectures }\end{array}$} & $\begin{array}{l}\text { - You have attended only one public } \\
\text { lecture related to the field of } \\
\text { translation or another specialist field } \\
\text { of interest. } \\
\text { - You have summarized the main } \\
\text { points of the lecture but you do not } \\
\text { express your opinion in relation to } \\
\text { these ideas, nor the usefulness of } \\
\text { the lecture you have attended. } \\
\text { - You have made a lot of mistakes in } \\
\text { grammar, spelling and punctuation } \\
\text { (more than 13). }\end{array}$ & $\begin{array}{l}\text { - You have attended two public } \\
\text { lectures that are loosely related to } \\
\text { the field of translation or another } \\
\text { specialist field of interest. } \\
\text { - You have summarized the main } \\
\text { points of the lecture but you do not } \\
\text { express your opinion in relation to } \\
\text { these ideas, nor the usefulness of } \\
\text { the lectures you have attended. } \\
\text { - You have made many mistakes in } \\
\text { grammar, spelling and punctuation } \\
(9-12) \text {. }\end{array}$ & $\begin{array}{l}\text { - You have selected two public } \\
\text { lectures loosely related to the field } \\
\text { of translation or another specialist } \\
\text { field of interest. } \\
\text { - You have summarized the main } \\
\text { points of the lecture; you have } \\
\text { expressed your opinion in relation to } \\
\text { these ideas, but you have not } \\
\text { commented on the usefulness of the } \\
\text { lectures you have attended. } \\
\text { - You have made some mistakes in } \\
\text { grammar, spelling and punctuation } \\
\text { (4-8). }\end{array}$ & $\begin{array}{l}\text { - You have selected two public lectures clearly } \\
\text { related to the field of translation or another } \\
\text { specialist field of interest. } \\
\text { - You have summarized the main points of the } \\
\text { lecture. You have expressed your opinion in } \\
\text { relation to these ideas and the usefulness of } \\
\text { the lectures you have attended. } \\
\text { - You have made none or few mistakes in } \\
\text { grammar, spelling and punctuation (0-3). }\end{array}$ \\
\hline & $0-0.374$ each lecture & $0.0374-0.74$ each lecture & $0.75-1.125$ each lecture & $1.125-1.5$ each lecture \\
\hline
\end{tabular}




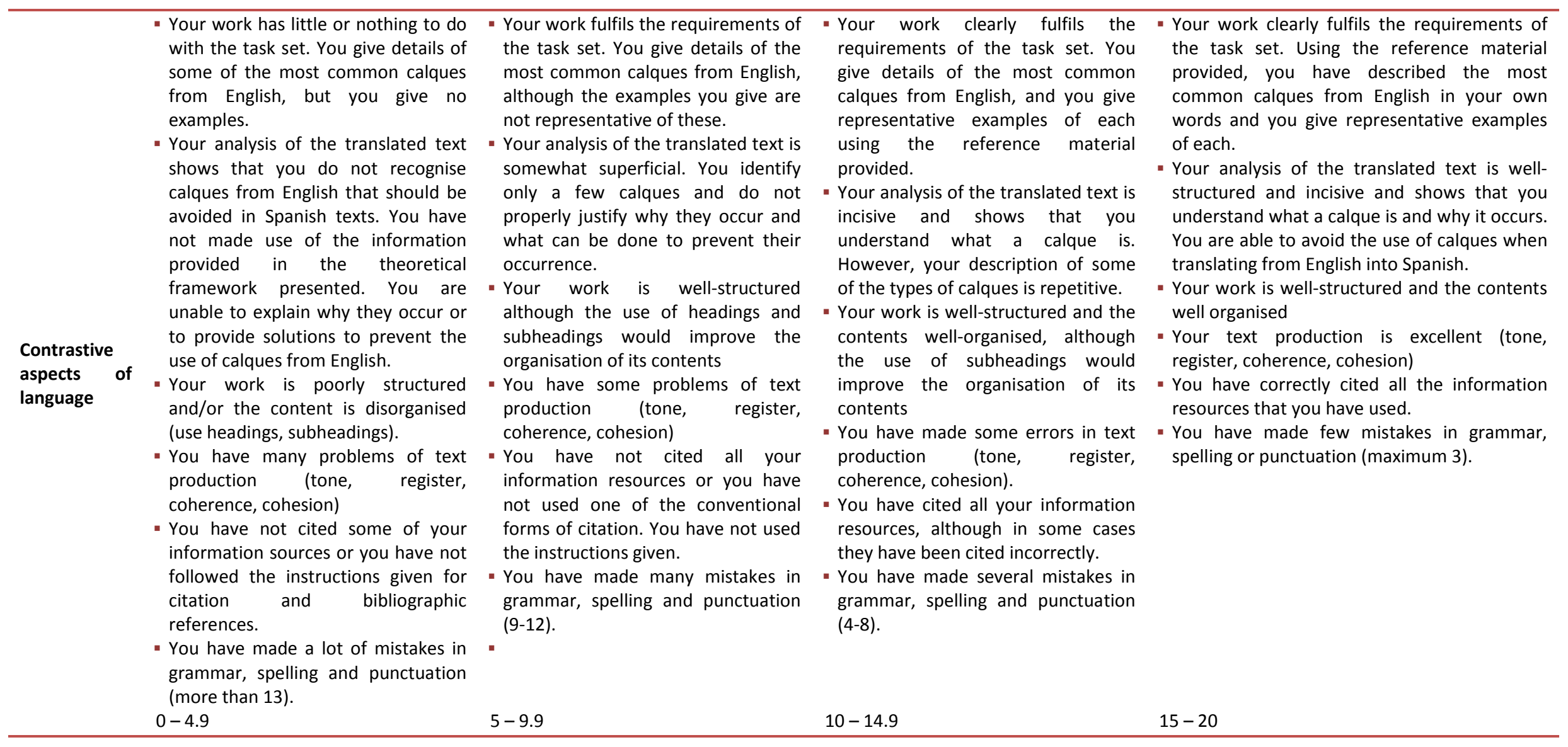




\begin{tabular}{|c|c|c|c|}
\hline $\begin{array}{l}\text { - You have not organised the content } \\
\text { of your portfolio satisfactorily and it } \\
\text { is difficult to locate the different } \\
\text { entries. } \\
\text { - You have made no use of different } \\
\text { fonts, colours, page position, etc. for } \\
\text { the presentation of your portfolio. } \\
\text { - You have made too many errors in } \\
\text { your text editing: margins; spacing } \\
\text { between words; format of } \\
\text { titles/headings and subheadings is } \\
\text { inconsistent. }\end{array}$ & $\begin{array}{l}\text { - The content of your portfolio is } \\
\text { somewhat disorganised although } \\
\text { eventually each entry can be } \\
\text { located. } \\
\text { - You have made an effort to use } \\
\text { different fonts, colours, page } \\
\text { position, etc. to enhance the } \\
\text { presentation of your portfolio, but } \\
\text { your formatting has not been } \\
\text { consistent throughout. } \\
\text { - You have made a lot of errors in your } \\
\text { text editing: margins; spacing } \\
\text { between words; format of headings } \\
\text { and subheadings is inconsistent. }\end{array}$ & $\begin{array}{l}\text { - The content of your portfolio is } \\
\text { somewhat disorganised although } \\
\text { each entry can eventually be located } \\
\text { thanks to the index you provide. } \\
\text { - You have used fonts, colours, page } \\
\text { position, etc. to advantage in the } \\
\text { presentation of your portfolio. } \\
\text { - You have made some errors in your } \\
\text { text editing: margins; spacing } \\
\text { between words; format of headings } \\
\text { and subheadings is inconsistent. }\end{array}$ & $\begin{array}{l}\text { - The content of your portfolio is well organised } \\
\text { and includes an index to facilitate } \\
\text { consultation. } \\
\text { - The presentation of your portfolio is excellent. } \\
\text { You have made good use of fonts, colours, } \\
\text { page position, margins, etc. } \\
\text { - You have made no errors in your text editing: } \\
\text { margins; spacing between words; format of } \\
\text { headings and subheadings is inconsistent. }\end{array}$ \\
\hline $0-0.24$ & $0.25-0.49$ & $0.49-0.74$ & $0.75-1$ \\
\hline
\end{tabular}

